\title{
ETHNOCULTURAL AGRARIAN TRADITIONS: SOCIO-CULTURAL DIMENSION OF DEVELOPMENT
}

\author{
(C) Vadim N. Goncharov, Olga Yu. Kolosova, Ekaterina Yu. Litvinova
}

\author{
North-Caucasus Federal University, Krasnodar University of Ministry \\ of Internal Affairs of Russian Federation, Stavropol, Russian Federation \\ science-almanac@mail.ru
}

In the process of ethnographic studies of modernity, the main question arose regarding the social sphere, its entities and forms, which are defined as a social connection. The problems of public relations are considered by representatives of various research areas, primarily within the framework of sociological sciences. In addition, representatives of such scientific disciplines as pedagogy, psychology, psychiatry, who in the accelerating process of civilization of the modern world see a threat to a person who is becoming increasingly lonely, trace the role and importance of public relations in certain combinations of people in their research of current problems. This threat is compounded, in particular, by constant neuropsychiatric tension, haste, an excess of information, as well as depersonalization of public relations. The public relation represents an organized system of relations, institutions, means of public control that unites individuals, subgroups and other constituent elements of the combination, into integrity. Each combination must be internally organized and streamlined. Considering agrarian traditions in the context of the socio-cultural sphere, some of their theoretical aspects are clarified. It is shown that agrarian traditions act as a kind of phenomenon in the general system of folk culture.

Key words: public consciousness, traditional rites, social action, agricultural culture, ethnos, sociocultural relations.

[В.Н. Гончаров, О.Ю. Колосова, Е.Ю. Литвинова Этнокультурные аграрные традиции: социально-культурный аспект развития]

В процессе этнографических исследований современности возник основной вопрос, касающийся общественной сферы, ее сущностей и форм, которые определяются как социальная связь. Проблематика общественной связи рассматривается представителями различных исследовательских направлений прежде всего в рамках социологических наук. Кроме того, роль и значение общественных связей в определенных совокупностях людей прослеживают в своих исследованиях актуальных проблем современности представители таких научных дисциплин, как педагогика, психология, психиатрия, которые в ускоряющемся процессе цивилизации современного мира видят угрозу для человека, становящегося все более одиноким. Эта угроза усугубляется, в частности, постоянным нервнопсихическим напряжением, спешкой, избытком информации, а также обезличиванием общественных отношений. Общественная связь представляет организованную систему отношений, институтов, средств общественного контроля, сплачивающую личности, подгруппы и другие составные элементы совокупности в целостность. Каждая совокупность должна быть внутренне организована и упорядочена. Рассматривая аграрные традиции в контексте социально-культурной сферы, выясняются некоторые их теоретические аспекты. Показано, что аграрные традиции выступают как своеобразный феномен в общей системе народной культуры.

Ключевые слова: общественное сознание, традиционные обряды, социальное действие, земледельческая культура, этнос, социально-культурные отношения.

Vadim N. Goncharov - Ph.D. (Advanced Doctorate) in Philosophy, Associate Professor, North-Caucasus Federal University, Stavropol, Russian Federation.

Olga Yu. Kolosova - Ph.D. (Advanced Doctorate) in Philosophy, Associate Professor, Krasnodar University of the Ministry of Internal Affairs of the Russian Federation, Stavropol, Russian Federation.

Ekaterina Yu. Litvinova - Ph.D. in Pedagogy, Assistant Professor, North-Caucasus Federal University, Stavropol, Russian Federation. 
Гончаров Вадим Николаевич - доктор фрилософрских наук, доцент, Северо-Кавказский федеральный университет, е. Ставрополь, Российская Федерация.

Колосова Ольга Юрьевна - доктор фрилософрских наук, доцент, Краснодарский университет Министерства внутренних дел Российской Федерации, г. Ставрополь, Российская Федерация.

Литвинова Екатерина Юрьевна - кандидат педагогических наук, старший преподаватель, Северо-Кавказский федеральный университет, е. Ставрополь, Российская Федерация.

Studying modern socio-economic and cultural reality of rural settlements, we are convinced that the process of change is taking place in different ways, and in this regard modern rural societies are characterized by significant differentiation. Among many factors that differentiate the development of the village, the main importance is its own historical tradition, which determines the identification of certain regions, rural collectives specific according to the culture.

Agriculture has played a huge role in the history of mankind. By gaining experience in cultivating cultivated plants, the man has shifted the real prospects of his existence and development. It is the accumulated experience of growing agricultural crops, which has spread to a certain collective that inherits it, that is transformed into a socio-industrial, organized stereotype, that is, into an agrarian tradition. Agrarian knowledge, which came in the process of labor activity, was fixed and formed into the simplest system of traditional rites and customs, becoming a part of economic and general folk culture. The most important question of the place and role of agrarian traditions both within the framework of the culture of agriculture and in the system of all traditional culture has not been considered yet. Such aspects as the dynamics of structural elements of traditions in relation to the level of social development on different synchronous historical sections, which carry out historical continuity, have been overlooked up to the present. Historical continuity as the highest value is closely related to historical memory [12, pp. 41-47], guarantees the proper level and quality of the obtained cultural product, which contributes to the dialogue of cultures that determines modern sociality [1, pp. 168-177]. We can also speak about the definitive scope of this concept in this section of culture and structural and functional characteristics and other phenomena. Sporadically, without defining the semantics of this phenomenon, some researchers from the local agrarian process identified certain stereotyped fragments and considered them as agrarian traditions, without placing them in the corresponding logical series of general agricultural culture, without defining the space-time frame at least in the Slavic ethnocultural array in which these agrarian stereotypical phenomena developed.

In the $20^{\text {th }}$ century, the importance of folk art was increased by its awareness. That gave it the rank of an exponent of the artistic creativity of peasants in the field of culture. At the same time, popular art being wildly recognized had great opportunities to take on the role of a link between culture of peasants and other social strata. When folk art was discovered as a cultural value, it began not only to serve its environment, but also be perceived by other civic circles, which adapted its various forms and variants.

The search for concepts and models of national culture and national art is created with the participation of folk culture. These concepts contributed to the development of self-consciousness and social consciousness when making connections with the values of folk culture. According to these concepts, the concept of folk tradition covered those elements of culture that, having received recognition in the peasant environment, created a certain internal organization of its complexes. These elements were introduced into national culture as the heritage of the peasant class, which took its own position as a result of the social revolution, one of the directions of these programs of actions was the creation of art for the masses; they determined the national character. The national character can be 
found by examining the national education system [4, pp. 28-34]. It is necessary to organize a system of upbringing and education based on scientific research of forms, methods, directions and mechanisms of personal development [13, pp.15-18]. Dialogue and interaction of cultures provide... " promoting positive attitudes towards cultural differences" [5, pp. 7-10], "characterizing a representative model of "a risk society "[7, pp. 196-202]. "Culture is understood as the inner essence of human ideas..." [3, pp. 3-9]. "Culture is an essential characteristic of the social sphere of society, it is inseparable from the social activity of a person" [10, pp. 74-78], one way or another, culture determines the socio-cultural development of society [11].

Noting only some positions of rural society in relation to its own culture, it should be emphasized that they are crucial for the further existence of folk art. They, in turn, are influenced by the policy of the state, its attitude to folk art, which, one way or another, forms the spiritual sphere of society, reflecting the qualitative level of development of social consciousness [9, pp. 18-22].

The agrarian tradition as a partial, but very important phenomenon, in the general context of folk culture has got a complex mechanism of formation and further improvement in the public system, determines... "human quality and the resulting ability of social subjects to purposeful interaction with the environment " [14, pp. 282-284], "complex interaction of various types of social communication" [2, pp. 5-10]. It acts structurally as an integral phenomenon, combining specifically defined components: technological techniques and agricultural skills, as well as its spiritual sphere, expressed in customs, rites, rituals, beliefs, accompanying stereotyped forms of agricultural activity. So that this variety of elements with different content will be able to become a tradition, a certain space is needed in which they would unite into a single mechanism in a large social team, that is, the creation of conditions in which agricultural production will achieve a socially stereotyped state.

Speaking of tradition as an expression of social and collective experience reproduced in various human collectives in a specific area, one should also take into account the substantive area of its disclosure. The whole agrotechnical process, which becomes traditional, falls into several technological stages with the defined functional scope and area of social action. These include socio-communicative traditions, which seem to fall out of the agro-technical process itself, but are associated with it organically; these are socioeconomic stereotypes.

The ritual actions and beliefs that make up a single whole are closely connected with technological traditions. The traditional agrarian calendar reflects the nature of the interaction of agrarian-industrial traditions with their socio-spiritual sphere, takes into account the religious cult that forms religious consciousness.

The transmission of traditional agrarian skills from generation to generation took place through a variety of festive rites, customs and other socio-spiritual phenomena. In folklore and ritual forms, projections of practical activity were preserved, when considering them, original paintings of agro-industrial life arise. Folk wisdom as an empirical generalization is embodied in the agricultural annual calendar that arose in ancient times, most comprehensively.

From literary and especially ethnographic materials one can see the peculiar structure of the agrarian national calendar and its functional directions, different in their effective strength. Taking into account the functional orientation of holidays of individual economic and calendar periods, it is possible to distinguish rituals of a conservatory nature, which fall in winter and partly autumn periods, and rituals directly related to the certain field work.

As evidenced by field materials from historical and ethnographic studies, ritual actions were of the nature of conservatory magic. Their goal is to ensure the development of plants throughout the growing season by means of imitative-symbolic magic. Traditional agrarian motifs can be traced in the folklore of Christmas holidays most vividly: calendar 
folk songs, religious carols. They are known to all Slavic peoples and associated with pagan beliefs. The closer to field work, the more substantive the rituals, magical actions look. In spring holidays, rituals of direct, momentary purpose, bearing echoes of conservatory content, prevail.

In spring church holidays, motifs of sowing and traditions aimed at preserving plants during growing season performed in various forms of religious and magical ceremonies. The religious-mystical attributes of rituals had nothing to do with real experience. Images of agricultural crops were endued with symbolic and agricultural content.

Among the traditional agricultural rites of the summer-autumn calendar cycle, those that are directly related to production activities were allocated first. Motifs of agrarian symbolics permeate, in particular, Kupala holidays.

Thus, we meet with the dual nature of the traditional agrarian calendar, when, according to ritual-magical scenarios of verbal or specific-subject content, conditional predictive predictions were made and rational actions were carried out, prompted by natural phenomena such as animal behavior, atmospheric precipitation.

Traditional calendar holidays were full of agrarian conservatory magic and became a certain system that introduced agrarian-industrial traditions into the sphere of the population lifestyle.

Each historically formed agrarian tradition is endued with a certain production and social function. In order not to lose its content, it must have a mechanism for stabilizing and transferring socially stereotyped agrarian experience to subsequent generations. The important role in this process is played by socio-communicative traditions: labor family education, agrarian ritual actions, calendar holidays, through which agrarian-industrial traditions are introduced into the existing lifestyle. Agrarian traditions acquire a peculiar structure consisting of certain components: technological skills and socio-communicative stereotypes. The formation of tradition in the historical and ethnographic field takes place with the inclusion of both technological techniques and certain components from the spiritual sphere. Before going to the field to plow the land, a number of magical rituals were performed. It should be emphasized that soil preparation traditions, as well as others, have their own special structure, which is related to a certain ethnocultural area. Even in a separate ethnic territory, there are identities not only in technological techniques, which are determined by many socio-economic, geo-ecological factors, but also in the spiritual sphere, manifested in the public consciousness, reflecting the requirements for subsequent conscious activity [6, pp. 14-17].

There is a different set of components in the tradition of sowing. Among them there are certain customs and ritual actions. Throughout the ethnic territory, they are identical in content, although partly of various forms. People strictly adhered to the established ritual tradition of consecrating on one of the holy days a small number of seeds, which were necessarily consumed at the time of sowing. Locally, there was a ritual of burrowing into the ground of consecrated objects such as prosphora or several grains during the sowing. By custom, it was considered mandatory so that the person chosen in the village, who was believed to provide a good harvest, began to sow the field.

In the traditions of crop care during growing season, there are no customs, rites and rituals, but conservatory magical actions performed on the days of calendar holidays of winter and spring periods are traced. Contact magic was also observed when, at the first plowing, the man waved an empty bag over the field, as if getting rid of empty grains.

In harvest traditions, many components are concentrated with ritual actions with varying saturation. In these rites, rituals and customs, all irrational and rational knowledge was invested, so that not to lose the already visible fruits of their works and worries.

The structural elements of socio-communicative agrarian traditions related to rituals and customs of invitations for joint work or with participation in joint tilling of land are pecu- 
liar in content. Each of them one of the defining components is highlighted. The example of a popular tradition of land use reveals the variant based only on empirical age-old agricultural knowledge and forming a certain system, based on a stereotypical mechanism of periodic use of land.

Holding of agrarian holidays dedicated to the time of completion of individual field work can be considered as an essential part of the lifestyle. Such holidays were filled with joy for the done work, glorifying which, it was possible to achieve final success, that was an abundant harvest. The emergence and existence of them were most often local in nature.

The theatricalization of agrarian traditional holidays provided for the identification of the most important part of the spiritual life of the public collective: song and narrative folklore, agrarian sacred magical actions. Agrarian and production traditions were an integral part of the way of life of peasants.

The different role of agrarian traditions in the way of life is traced. The active position depends on the set of components of the spiritual sphere involved in the stabilization of traditions. Traditions with a full set of traditional components are noted with great dynamicity: customs, rites, rituals, beliefs, agrarian holidays, which include the traditions of field cultivation and harvesting.

Since agrarian traditions developed in certain human communities under the influence of socio-economic, cultural-traditional, environmental factors, they must be considered in relation to different ethnographic groups, that determines the great variability of this phenomenon even within the same ethnos. Agrarian traditions, having a common ethnic, and in some elements even Common-Slavic basis, are differentiated at the level of ethnographic groups, in which the introverted function of traditions, determined within the framework of this ethno-cultural region, is visible.

As a result of the natural process of mutual enrichment, which takes place both within the ethnic group and under the influence of inter-ethnic communion, the traditions of agriculture existing in a certain ethnocultural region change, new agricultural stereotypes are formed.

As we see, agrarian traditions stabilize socio-cultural relations in certain historical frameworks. They largely predetermined the progressive nature of the development of agricultural culture, consolidating the best, productive technological techniques of the agricultural process. The important socio-productive function of agrarian traditions was realized in the labor and aesthetic education of a peasant. Agrarian traditions act as a kind of phenomenon in the general system of folk culture.

Some agrarian traditions have lost their social and productive importance in our time, when the production of crops is carried out on a new basis, taking into account objective data on the state of the soil, environmental conditions and thereby levelling traditionally established technological and worldview stereotypes. The reminiscent phenomena of agrarian traditions in modern agriculture are manifested in agrarian festivities on the occasion of the completion of spring field work or harvesting. Although they carry a social burden, the rites themselves no longer act as a kind of mechanism for stabilizing and reproducing social relations and the way of life of the population. They cannot be defined as traditions in the modern scientific sense. These ritual actions perform a certain aesthetic emotional function; they affect the production sector, the increase in labor productivity due to the factor of emotional and psychological influence. Modern festive rites are aimed at developing industriousness, forming an aesthetic attitude to work, respect for a working man.

Agrarian traditions as dynamic phenomena are subject to changes until they completely lose value under the influence of basic superstructure changes. At the present stage of agrarian development, where the production of agricultural crops is put on a new 
basis, the main technological processes are mechanized, centuries-old traditions have lost their former significance as a stabilizing and reproducing mechanism of stereotyped collective experience.

\section{Лumepamypa}

1. Бакланова О.А., Бакланов И.С. Современная российская социальность в контексте социального конструкционизма /I Вопросы социальной теории. 2015. Т. 7. №1-2. С. 168-177.

2. Бакланова О.А., Бакланов И.С. Контуры типологического исследования социальности современного общества // Известия Саратовского университета. Новая серия. Серия: Философрия. Психология. Педагогика. 2014. Т. 14. № 2-1. С. 510.

3. Берковский В.А., Тронина Л.А. Социально-исторический аспект взаимодействия этнической культуры и личности в контексте общественного развития // Научный альманах стран Причерноморья. 2019. №1(17). С. 3-9.

4. Говердовская E.B. Социокультурные и этнологические особенности региона основа модернизации высшего образования на Северном Кавказе // Ученые записки университета им. П.Ф. Лесгафтта. 2007. № 7. С. 28-34.

5. Говердовская E.В. Особенности проектирования образовательного пространства высшей школы в поликультурном регионе // Экономические и гуманитарные исследования регионов. 2014. № 4. С. 7-10.

6. Говердовская Е.В., Болховской А.Л. Информационная парадигма современного общества: социально-философский и педагогический обзор концепций // Гуманитарные, социально-экономические и общественные науки. 2013. № 7-1. С. 1417.

7. Душина Т.В., Микеева О.А. «Общество риска» как репрезентативная модель современного социума // Личность. Культура. Общество. 2009. Т. XI. №4. С. 196-202.

8. Гуриева Л.К. Новые подходы к инновационному развитию регионов // Гуманитарные и социальные науки. 2013. № 5. С. 35-42.

9. Ерохин А.М. Религиозное сознание в контексте общественных отношений // Гуманитарные и социально-экономические науки. 2015. №2(81). С. 18-22.

10. Ерохин А.М. Социально-фрилософские аспекты развития культурной сферы общества // Экономические и гуманитарные исследования регионов. 2016. № 1. C. 74-78.

11. Колосова О.Ю. Системно-методологические основания экологического знания // Гуманитарные и социально-экономические науки. 2008. № 5. С. 28-33.

12. Кулешин М.Г., Леонова Н. А., Немашкалов П. Г. Концептуальные основы социальной ответственности корпоративных структур: исторический аспект // Научный альманах стран Причерноморья. 2019. №1(17). С. 41-47.

13. Лобейко Ю.А. Социально-педагогический аспект активности личности в системе общественного развития // Экономические и гуманитарные исследования регионов. 2015. №1. С. 15-18.

14. Лобейко Ю.А. Социальная активность личности в обществе: социальнопедагогические аспекты формирования // European Social Science Journal. 2014. № 7-2(46). С. 282-284. 


\section{References}

1. Baklanova O.A., Baklanov I.S. Sovremennaia rossiiskaia sotsialnost v kontekste sotsialnogo konstruktsionizma. Voprosy sotsialnoi teorii. [Modern Russian sociality in the context of social constructionism. Questions of social theory]. 2015. V. 7. No. 1-2. pp. 168-177 (in Russian).

2. Baklanova O.A., Baklanov I.S. Kontury tipologicheskogo issledovaniia sotsialnosti sovremennogo obshchestva. Izvestiia Saratovskogo universiteta. Novaia seriia. Seriia: Filosofiia. Psikhologiia. Pedagogika. [Contours of typological study of the sociality of modern society. Izvestia, Saratov University. New series. Series: Philosophy. Psychology. Pedagogics]. 2014. V. 14. No. 2-1. pp. 5-10 (in Russian).

3. Berkovsky V.A., Tronina L.A. Socio-historical aspect of the interaction of ethnic culture and personality in the context of social development. Science almanac of Black Sea region countries. 2019. No. 1(17). pp. 3-9.

4. Goverdovskaya E.V. Sotsiokulturnye i etnologicheskie osobennosti regiona - osnova modernizatsii vysshego obrazovaniia na Severnom Kavkaze. Uchenye zapiski universiteta im. P.F. Lesgafta. [Sociocultural and ethnological features of the region are the basis for the modernization of higher education in the North Caucasus. Scientific notes of the university named after P.F. Lesgaft]. 2007. No. 7. pp. 28-34 (in Russian).

5. Goverdovskaya E.V. Osobennosti proektirovaniia obrazovatelnogo prostranstva vysshei shkoly v polikulturnom regione. Ekonomicheskie i gumanitarnye issledovaniia regionov. [Features of the design of the educational space of higher education in the multicultural region. Economic and humanitarian research of the regions]. 2014. No. 4. pp. 7-10 (in Russian).

6. Goverdovskaya E.V., Bolkhovskoy A.L. Informatsionnaia paradigma sovremennogo obshchestva: sotsialno-filosofskii i pedagogicheskii obzor kontseptsii. Gumanitarnye, sotsialno-ekonomicheskie i obshchestvennye nauki. [Information paradigm of modern society: socio-philosophical and pedagogical review of concepts. Humanitarian, socio-economic and social sciences]. 2013. No. 7-1. pp. 14-17 (in Russian).

7. Dushina T.V., Mikeeva O.A. "Obshchestvo riska" kak reprezentativnaia model sovremennogo sotsiuma. Lichnost. Kultura. Obshchestvo. ["Society of Risk" as a representative model of modern society. Personality. Culture. Society]. 2009. V. XI. No. 4. pp. 196-202 (in Russian).

8. Gurieva L.K. Novye podkhody k innovatsionnomu razvitiiu regionov. Gumanitarnye i sotsialnye nauki. [New approaches to innovative development of regions. Humanitarian and social sciences]. 2013. No. 5. pp. 35-42 (in Russian).

9. Erokhin A.M. Religioznoe soznanie v kontekste obshchestvennykh otnoshenii. Gumanitarnye i sotsialno-ekonomicheskie nauki. [Religious consciousness in the context of social relations. Humanitarian and socio-economic sciences]. 2015. No. 2(81). pp. 18-22 (in Russian).

10.Erokhin A.M. Sotsialno-filosofskie aspekty razvitiia kulturnoi sfery obshchestva. Ekonomicheskie i gumanitarnye issledovaniia regionov. [Socio-philosophical aspects of the development of the cultural sphere of society. Economic and humanitarian research of the regions]. 2016. No. 1. pp. 74-78 (in Russian).

11. Kolosova O.Yu. Sistemno-metodologicheskie osnovaniia ekologicheskogo znaniia. Gumanitarnye i sotsialno-ekonomicheskie nauki. [Systematic and methodological 
foundations of environmental knowledge. Humanitarian and socio-economic sciences]. 2008. No. 5. pp. 28-33 (in Russian).

12. Kuleshin M.G., Leonova N.A., Nemashkalov P.G. Conceptual foundations of social responsibility of corporate structures: historical aspect. Scientific almanac of Black Sea region countries. 2019. No. (17). pp. 41-47.

13. Lobeyko Yu.A. Sotsialno-pedagogicheskii aspekt aktivnosti lichnosti v sisteme obshchestvennogo razvitiia. Ekonomicheskie i gumanitarnye issledovaniia regionov. [Socio-pedagogical aspect of activity of personality in the system of social development. Economic and humanitarian research of regions]. 2015. No. 1. pp. 15-18 (in Russian).

14.Lobeyko Yu.A. Sotsialnaia aktivnost lichnosti v obshchestve: sotsialnopedagogicheskie aspekty formirovaniia. European Social Science Journal. [Social activity of personality in society: socio-pedagogical aspects of formation. European Social Science Journal]. 2014. No. 7-2(46). pp. 282-284. 